\title{
ON THE TWO POORLY KNOWN ORTHOTRICHUM SPECIES FROM NORTH ASIA
} О ДВУХ МАЛОИЗВЕСТНЫХ ВИДАХ РОДА ОRТНОTRICHUM ИЗ СЕВЕРНОЙ АЗИИ

\author{
Vladimir E. FEDOSOV ${ }^{1}$, Alina V. FedOROVA ${ }^{2} \&$ ELENA A. IGNATOVA $^{1}$ \\ ВЛАДИМИР Э. ФЕДОСОВ ${ }^{1}$, АЛИНА В. ФЕДОРОВА ${ }^{2}$, ЕЛЕНА А. ИГНАТОВА $^{1}$
}

Abstract

Recent revision of Asiatic specimens of the genus Orthotrichum s. str. revealed two species widely distributed and rather frequent in northern Asia, which however differ from all currently recognized species. One of them includes plants growing on silted bases of willows and fallen trees in flood valleys; its specimens were previously referred to $O$. holmenii, but in fact it fits $O$. sibiricum, a species described from the lower course of Yenisei River in 1890, but later reduced to the synonymy of $O$. pallens. However, $O$. sibiricum differs from European $O$. pallens in high, branched papillae and pointed, not blunt, leaf apex, and they are also clearly distinct in ITS sequences. Orthotrichum sibiricum occurs in Nenets Autonomous disctict in NE European Russia, the Polar and Subpolar Urals, the lower course of the Yenisei River, on the Anabar Plateau, Orulgan Range and in Transbaikalia. The second species is also superficially somewhat similar to $O$. pallens, at least most its collections were so named in herbaria. However, it is characterized by having hyaline cells at leaf apices, and usually 1-2 teeth nearby it, as well as branched papillae on laminal cells, immersed to emergent capsules with 8 ribs at entire urn length, stomata half-covered by subsidiary cells, exostome teeth in pairs, 8 or 16 endostome segments, and smooth, hairless calyptra. This species grows mostly on siliceous rocks in cold areas of Siberia, both in northern regions and in high mountains. It is described as a new species, O. hyperboreum; its range includes Polar Urals, Byrranga Mts. in Taimyr, Anabar Plateau, Orulgan Range in the lower course of Lena River, and Chukotka.

Резюме

Ревизия образцов рода Orthotrichum s. str. показала, что два широко распространенных и нередких на севере Азиатской России вида не относятся ни к одному из хорошо известных видов рода. Растения, произрастающие на заиленных основаниях стволов ив и валежинах, ранее относились нами к O. holmenii, который с недавних пор рассматривается в качестве синонима O. scanicum. Согласно результатам наших молекулярно-филогенетических исследований, основанных на последовательностях ITS, сибирские растения не близки к $O$. scanicum; также они отличаются от этого вида морфологически, но соответствуют описанию и идентичны типу описанного Гренваллем на основании сборов из низовьев Енисея $O$. sibiricum, впоследствии сведенному в синонимы к $O$. pallens. Наши образцы заметно отличаются от O. pallens морфологически и по последовательностям ITS, так что название O. sibiricum восстановлено для вида, встречающегося на Полярном и Приполярном Урале, в низовьях Енисея, на Анабарском плато, хребте Орулган и в Забайкалье и ранее относимого к $O$. holmenii; идентичность типовых образцов $O$. holmenii нуждается в проверке. Второй широко распространенный в азиатской Гипоарктике вид встречается исключительно на затененных глыбах силикатных горных пород. Ранее образцы этого вида были определены как O. pallens, несмотря на заметные отличия в морфологии, экологии и закономерностях распространения. Молекулярно-филогенетические данные также свидетельствуют в пользу самостоятельности этого таксона, который описывается под названием O. hyperboreum sp. nov. Вид отличается комбинацией разветвленных папилл, гиалиновых зубцов на верхушке листа, погруженных или слегка выступающих из перихециев коробочек с 8 мощными ребрами, погруженных устьиц, наполовину прикрытых побочными клетками, попарно срастающихся зубцов экзостома, 8 или 16 сегментов эндостома, гладких голых колпачков, а также произрастанием на силикатах и распространением в азиатской Арктике и Гипоарктике (Полярный Урал, Бырранга, Анабарское плато, хребет Орулган, Чукотка).

KEYWORDS: Orthotrichaceae, Russia, Arctic, Subarctic, Orthotrichum sibiricum, Orthotrichum hyperboreum, biogeography, integrative taxonomy

1 - Moscow State University, Biological Faculty, Geobotany Dept., Moscow 119234 Russia - Россия 119234, Москва, Московский университет, Биологический факультет, каф. геоботаники. E-mails: fedosov_v@mail.ru, arctoa@list.ru.

2 - Lomonosov Moscow State University, Belozersky Institute of Physico-Chemical Biology, Moscow 119991 Russia. E-mail: alina_77777@mail.ru 


\section{INTRODUCTION}

Extensive collections of bryophytes made in 1876 during Swedish expedition along the Yenisei River by Hampus Wilhelm Arnell brought numerous specimens partly referred to previously unknown species. In the course of further study of the Siberian moss flora in $20^{\text {th }}$ and early $21^{\text {st }}$ century, some of these species were found in new localities, while some others are still known mostly from the type collections. Among other poorly known species, Dorcadion sibiricum Grönvall in Lindberg \& Arnell was described based on specimens from three localities in lower course of Yenisei River and for a long time it was known only from that area. Warnstorf (1913) transferred this species to the genus Orthotrichum without any comments on its identity and relationship. After that, this name was forgotten for a long time until Jetty Lewinsky studied the type material while prepared the taxonomic treatment of Orthotrichaceae in Greenland, and found it to be conspecific with $O$. pallens Bruch ex Brid. (Lewinsky, 1977); this solution was followed by Ignatov et al. (2006).

Since the beginning of $21^{\text {st }}$ century, an extensive studies of north Siberian moss flora resulted in plenty of specimens. These collections were partly identified and partly accumulated for the circumstantial revisions in the course of "Moss flora of Russia" project. Continental areas northward of $70^{\text {th }}$ parallel are not the place where one could estimate rich and difficult flora of Orthotrichum s.str. Thus, at first we used rather broad circumscriptions of species elaborated for Europe by Lewinsky (1993a,b; 1995); however, in some cases combinations of morphological characters even of rather common species did not fit perfectly to the existing descriptions. Further inflating of morphological circumscriptions of European species seemed to be inappropriate, so we started to search for more relevant names for north Siberian taxa. Plants with well emergent to shortly exserted capsules, 16 exostome teeth and 16 endostome segments of the equal length, growing on silt-covered willow bases in river valleys were identified as $O$. holmenii LewinskyHaapasaari (Fedosov et al., 2009). This species was described based on three specimens from Kazakhstan (Lewinsky-Haapasaari, 1996), but later it was considered to be conspecific with O. scanicum (Medina et al., 2009). The latter species was reported in Russia from the Baikal area, Hamar-Daban Range (Kazanovsky, 1991) and in Teberdinsky State Reserve, West Caucasus (Ignatova et al., 2008), both in environments quite different from those in Subarctic Siberia or xeric Alma-Ata surroundings in Kazakhstan.

The second widely distributed and locally frequent north Siberian Orthotrichum is quite remarkable due to a combination of "pallens-like" morphology (i.e., lanceolate leaves, immersed to short emergent capsules with eight ribs, exostome teeth fused in pairs, 8 or 16 endostome segments and pale, smooth, naked calyptrae) and strictly saxicolous growth. These specimens were referred to $O$. pallens in publications on regional floras (Afonina, 2004; Fedosov \& Ignatova, 2005; Fedosov et al., 2011; Ignatov et al., 2014), despite a differences in morphology, ecology and patterns of distribution. Hyaline teeth at leaf apex, composed of large, elongate, acute, protruding papillose cells are notable even for superficial study with the hand lens, and invariably numerous gemmae are not characteristic of $O$. pallens, which occurs in Europe mainly in temperate to hemiboreal climates, growing mostly on trees.

To sum up, since the integrative taxonomy implies dealing not only with the species morphology and molecular data, but with their ecology and distribution as well, it seems quite unlikely that these Siberian Orthotrichum entities represent one of well known European species. Since only three Orthotrichum species are quite widespread in Subarctic Siberia (the third one, O. anomalum Hedw., is common in places where calcareous bedrocks outcrop), it became necessary to check the identity of two other widespread taxa of Orthotrichum and to search for possible existing names for them. Aiming to prove our implications inferred from morphology, ecology and distribution, we employed a molecular phylogenetic approach.

\section{MATERIALS AND METHODS}

For morphological study, specimens from MW, MHA and LE were used. Nuclear ITS region was employed as the most variable and informative marker to resolve the relationships between the taxa of Orthotrichum. For molecular study, four specimens of "O. holmenii" and five specimens of "Siberian $O$. cf. pallens" were selected. Sequences of O. pumilum Sw. ex anon., O. pallens, O. scanicum and $O$. moravicum Plášek \& Sawicki were downloaded from GenBank and seven newly obtained sequences of these species were added. Some other more distantly related species of the genus were involved to provide an adequate representation of main phylogenetic lineages. In total, 35 sequences were included in the analysis, 24 sequences were obtained de novo. Specimen vouchers and GenBank accessions are in Appendix 1.

Laboratory protocol was nearly the same as in previous moss studies described in detail by, e.g., Gardiner et al. (2005). For amplification and sequencing of ITS we used the primers of Fiedorow et al. (1998). The same primers were used for sequencing. The obtained sequences were aligned independently using MUSCLE (Edgar, 2004), and modified manually using BioEdit 7.0.9.0 (Hall, 1999). Four sequences of Lewinskya speciosa (Nees) Lara, Garilleti \& Goffinet were included as an outgroup; all trees were rooted on the L. speciosaclade.

Best-scoring Maximum Likelihood (ML) tree was estimated using RaxML (Stamatakis, 2006) from 1000 independent searches each starting from distinct random trees. Robustness of the nodes was assessed using the thorough bootstrapping algorithm (Felsenstein, 1985) 


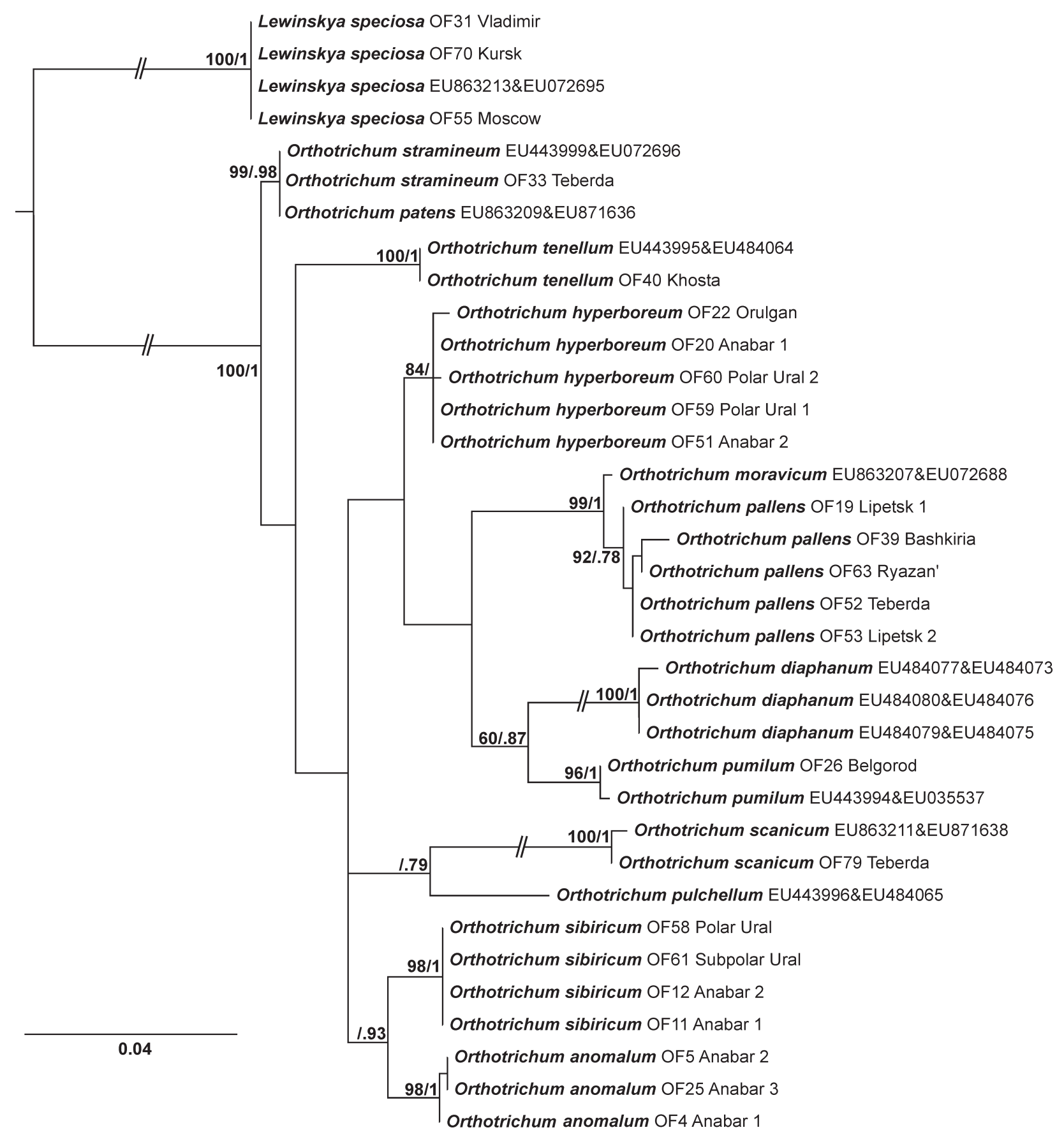

Fig. 1. The ML-based tree inferred from nuclear ITS1-2 seauences; bootstrap supports ( $>60)$ and posterior probabilities ( $>75)$ are above branches.

with 1000 iterations. Bayesian analysis was performed using MrBayes version 3.2.6 (Ronquist et al. 2012), running in two parallel analyses, consisting each of six Markov chains of 10000000 generations with a sampling frequency of one tree each 2.5 thousand generations and the chain temperature at 0.05 . Parameters of the substitution model were estimated during the analysis (six substitution categories, a gamma-distributed rate variation across sites approximated in four discrete categories and a proportion of invariable sites). Convergence of the anal- yses was evaluated using Tracer 1.4.1 (Rambaut \& Drummond 2007) to check that ESS values were all greater than 200 (default burning). The consensus tree was then combined after first $25 \%$ of trees were discarded as a burn-in. All analyses were performed on the Cipress Science Gateway (http://www. phylo.org/portal2).

\section{RESULTS}

In both ML and BA analyses twelve involved species of the genus Orthotrichum form an ultimately supported clade, though topologies inferred from these analysis 
slightly differ. The topology obtained from ML analysis with BS/PP values is shown in Fig. 1. Most of species, including " $O$. holmenii" (under the name $O$. sibiricum) and "Siberian $O$. cf. pallens" (O. hyperboreum) are found in monospecific more or less supported clades, though the higher level groupings are mostly not supported. The highly supported clade (BS 99, $\mathrm{PP}=0.98$ ) composed of two species with hairy vaginula, $O$. stramineum Hornsch. ex Brid. and $O$. patens Bruch ex Brid., splits on the first dichotomy. Then, after maximally supported $O$. tenellum Bruch ex Brid. clade, which splits on the next node, the not supported trichotomy with the remaining species crowns the tree.

It comprises three clades: (1) weakly supported $(\mathrm{PP}=0.93)$ clade of two subclades: O. holmenii (BS 98, $\mathrm{PP}=1$ ) and $O$. anomalum (BS 98, $\mathrm{PP}=1$ ); (2) weakly supported $(\mathrm{PP}=0.79)$ clade of single sequence of $O$. pulchellum Brunt. and maximally supported clade of two specimens of $O$. scanicum (BS 100, $\mathrm{PP}=1$ ); (3) not supported clade which comprises rather weakly supported clades of "Siberian $O$. cf. pallens" (BS=84), then highly sipported O. moravicum +O. pallens -clade (BS 99, $\mathrm{PP}=1)$, and weakly supported clades of two highly supported subclades formed by $O$. diaphanum Brid. (BS 100, $\mathrm{PP}=1$ ) and O. pumilum (BS 96, $\mathrm{PP}=1$ ).

In the tree inferred from Bayesian analysis, Orthotrichum-clade represents a polytomy with all-five specimens of "Siberian $O$. cf. pallens" in the basal position to the clades formed by all other species. The weakly supported $O$ pumilum \& $O$. diaphanum clade and large not supported polytomic clade with the rest of species are nested in this polytomy (Fig. 1a). The latter comprises (1) moderately supported clade of $O$. holmenii plus $O$. anomalum; (2) not supported clade of $O$. tenellum and $O$. stramineum plus $O$. patens; (3) weakly supported clade of $O$. scanicum plus $O$. pulchellum; (4) well supported clade of $O$ pallens plus $O$. moravicum.

\section{DISCUSSION}

Definitely a much more expanded dataset both in terms of taxonomical representation and number of employed markers is needed for Orthotrichaceae analysis. However, the obtained topologies are suggestive enough to estimate the taxonomic decisions for two poorly known Siberian taxa, which are in focus of the present study.

According to the obtained results, Subarctic specimens of "O. holmenii" are not related to the suboceanic O. pulchellum - O. scanicum - O. consimile group (Subgenus Pulchella sect. Pulchella), though all these species are similar in peristome morphology. Orthotrichum consimile was not included in the present study, while $O$. pulchellum and $O$. scanicum were found in one clade, while Siberian Subarctic "O. holmenii" formed another clade with another rather continental moss, O. anomalum of Subg. Orthotrichum (Fig. 1). Sawicki et al. (2012) also found that $O$. anomalum does not group with $O$. pallens, O. pumilum and other species of the Subgenus
Pulchella. This means that Subarctic Siberian "O. holmenii" is unlikely identical with $O$. scanicum.

Despite the name Orthotrichum sibiricum has been for a long time considered as synonym of $O$. pallens, and one can propose that it could be applied to our "Siberian $O$. cf. pallens", even superficial study of the protologue suggests that $O$. sibiricum has no single difference from $O$. holmenii as it is described by LewinskyHaapasaari (1996). In particular, according to the protologue, $O$. sibiricum has dirty blackish green leaves (due to growth in occasionally flooded habitats), emergent capsules, stomata half-covered by the subsidiary cells, teeth fused in 8 pairs, splitting during spore release, and 16 slightly appendiculate endostome segments of equal length. All these characters are cosistent with the description and illustrations provided by Fedosov et al. (2009) for $O$. holmenii and nearly identical illustrations were made by Lewinsky-Haapasaari (1996) from the type specimen(s) of $O$. holmenii, though gemmae do not occur in every northern specimen. In addition, according to the protologue, O. sibiricum grows on Alnaster and Salix trunks near streams, and just in the same conditions all Russian specimens of $O$. holmenii were collected. The type specimen of $O$. holmenii was collected "on shrub by stream".

Lectotype and isolectotype specimens of $O$. sibiricum in S were studied and they (1) fully correspond to the protologue; (2) are identical to our plants previously named as $O$. holmenii, and (3) fully correspond to the protologue of the latter species. Thus, we suggest that (1) the name should be resurrected, and (2) all Siberian specimens previously identified as $O$. holmenii are to be referred to $O$. sibiricum. We cannot put $O$. holmenii into synonymy under $O$. sibiricum confidently, since we have not studied the type material of the former, but it is quite likely that they belong to one species. Difference in their distribution patterns is not that significant since recently "O. holmenii" was found in Transbaikalia (South Siberia), while Kazakhstan specimens were collected at ca. $1200 \mathrm{~m}$, an equivalent to low elevation in Siberia.

Status of the second target taxon also seems to be obvious. Despite the grouping of "Siberian O. cf. pallens" is weakly supported, five obtained sequences are nearly identical and they definitely cannot be referred to any of the included species or a group of species ( $O$. pallens \& O. moravicum), since they form an almost maximally supported clade (BS 99, $\mathrm{PP}=1$ ). The present topology is likely caused by the "plesiomorphic" character of the "Siberian $O$. cf. pallens" ITS sequence, which almost lacks synapomorphic characters, though at least one unique substitution within the present dataset is shared by all five studied specimens. Thus, the molecular data obtained for the "Siberian $O$. cf. pallens" if not clearly support, than at least do not contradict their segregation in a separate species. It worth to be mentioned that European $O$. pallens apparently represents a floc of related 
species, and moreover, in the study of Sawicki et al. (2012) specimens corresponding to $O$. pallens morphologically were found in three not related clades: (1) with $O$. moravicum, (2) with $O$. pumilum and (3) with $O$. stramineum. Since sequences of their specimens are not available in GenBank, we cannot compare them with ones from "Siberian $O$. cf. pallens", but since the latter is close neither to $O$. pumium nor to $O$. stramine$u m$ and differs in distribution (O. pallens was described from Germany), our material definitely represents another species. The obtained topology reminds the one recently shown for Hedwigia emodica (Ignatova et al., 2016), which is widespread in the continental areas of Siberia and bears the set of plesiomorphic characters in its chloroplastic (trnL-trnF) and mitochondrial (Nad5) sequences.

Among existing names for this taxon, $O$. pallidum Grönvall looks especially well corresponding to "Siberian $O$. cf. pallens". However, this name in illegetimate (Lewinsky, 1977) and considering also that the old collections unlikely can be sequenced, reducing the evidence of the species identity, we propose to describe "Siberian $O$. cf. pallens" as a new species, O. hyperboreum (see below).

\section{TAXONOMY}

Orthotrichum sibiricum (Grönvall) Warnst., Hedwigia 53: 312. 1913. - Dorcadion sibiricum Grönvall in Lindb. \& Arnell, Kongl. Svenska Vetensk.-Akad. Handl. 23(10): 96. 1890. Type: Sibiria: Yenisei, Nikandrovskij ostrov, 70²0' lat., 15.VIII.1876, Arnell (Lectotype SB69146!; Isolectotypes S-B69147!, S- B69148!; selected by Lewinsky, 1977).

(?) Orthotrichum holmenii Lewinsky-Haapasaari, Bryologist 99: 1, f. 2, 5. 1996. Type: Kazakhstan, Alma Ata Oblast, Alma Ata Wilderness Preserve, Levii Talgar Valley, entrance to preserve. On shrub by stream, 1200 m (Holotype in MO). Not seen.

Wijk et al. (1964) provided the following cilation for this name, Orthotrichum sibiricum Grönvall, Nya Bidr. Kannedomen Nord. Orthotrichum, 10. 1887. This reference retained in Tropicos database (http://www.tropicos.org/Name/35173880, accessed 20 Dec. 2017), although already Lewinsky (1977) found that the species was not cited in this publication, and it was validated in Lindberg \& Arnell" "Musci Asiae borealis" in the genus Dorcadion.

The description and illustrations for this species were published recently by Fedosov et al. (2009), thus not repeated here. Additional localities of this species were reported later by Ignatov et al. (2014), Fedosov et al. (2011; 2015), Afonina et al. (2017). All these specimens were revisited in the course of preparing of the present paper, thus, according to our results, the species has rather broad hypoarctic-montane Asiatic distribution. It is not rare in valleys of some Siberian rivers, occasionally occurring, in addition to trunk bases, also on moist, shaded sandstone boulders.
Specimens examined: EUROPEAN RUSSIA: Nenetskij Autonomous Distr.: Middle course of Ad'zva River, 31.VII.2009, Ivanov \& Donskov 09-549 (MHA). ASIAN RUSSIA: YamaloNenetskij Autonomous Distr.: Polar Ural eastern slope, ca. 10 $\mathrm{km}$ northward Laborovaya Settl., brook valley southward Yanganape Range, 7.VIII.2017, Fedosov 17-2-115-1, 17-2-115-2 (MW). Khanty-Mansijsk Autonomous Distr: Berezovo Distr., Subpolar Urals, Puiva River middle course, 9.VIII.2015, Lapshina \& Skuchas (MW 9051021). Krasnoyarsk Territory, Taimyr Municipal District: Kotuyskoe Plateau, Maymecha River valley $2 \mathrm{~km}$ downstream Chopko River mouth, 20.VI.2009, Fedosov (MW 9049169); the same area, $9 \mathrm{~km}$ upstream Chopko River mouth, 23.VI.2009, Fedosov (MW 9049170); Kotuy River valley near Potakaj Creek mouth, 16.VIII.2011, Fedosov (MW 9049168, 9049171); the same area, 18.VIII.2011, Fedosov (MW 9051022); Khara-Tas Range, Eriechka River upper course, Nyamakit-Daldyn Creek mouth, 3.VIII.2013, Fedosov (MW 9051023). Republic Sakha (Yakutia): Eveno-Bytantaysky Distr., Orulgan Range, Enigan-Toloono Creek tributary upper course, 7.VIII.2011, Ignatov 11-3976 (MHA); Zabaikalsky Territory: Kalarsky Distr., Kodar Range, Syul'ban River valley, on rock outcrops, 16.VI.2015, Afonina 2415 (LE).

Orthotrichum hyperboreum Fedosov \& Ignatova, sp. nov.

Figs. 2-5.

Type: north periphery of the Anabar Plateau, slope of Fomich River valley $9 \mathrm{~km}$ upstream its mouth $\left(72.1251^{\circ} \mathrm{N}\right.$ $-110.338^{\circ} \mathrm{E}$, ca. $150 \mathrm{~m}$ alt.), on dolerite lump, 10.VII.2008, Fedosov 08-369 (Holotype MHA! Isotype MW!) .

Diagnosis. Orthotrichum hyperboreum resembles $O$. pallens in papillose leaf cells, short setae, immersed to emergent, strongly 8-ribbed capsules, stomata rather slightly covered by the subsidiary cells, exostome teeth in pairs, mostly 16 endostome segments and pale, naked, smooth calyptrae, but differs from the latter in having apiculate leaves with one (up to three) elongate hyaline apical cell, strongly thick-walled cells with spinelike protruding papillae just below apex, forked papillae on the leaf lamina, saxicolous growth and continental north Asian distribution.

Etymology. The species name reflects its distribution in high altitudes: all known localities are situated northward the polar circle, while the northernmost one was found in Byrranga Range, inner Taimyr, the northernmost continental mountain system, where the species is the only representative of the genus Orthotrichum s.str.

Description. Plants small, dark-green or, rarer, in lighter environments, yellow-green or bright green, in compact tufts. Stems $0.6-0.8 \mathrm{~cm}$ long, poorly branched, strongly tomentose in lower part. Leaves appressed, straight or slightly to moderately curved then dry, erect to spreading when moist, $1.8-2.3 \times 0.5-0.7 \mathrm{~mm}$, ovatelanceolate, distinctly keeled, obtuse or acute, apiculate; costa green, rather indistinct, ending just below leaf apex, with simple and forked papillae on abaxial surface; lamina unistratose; margins recurved from leaf base to near apex on both sides, entire or slightly crenulate distally due to protruding papillae, distinctly dentate at apex with 

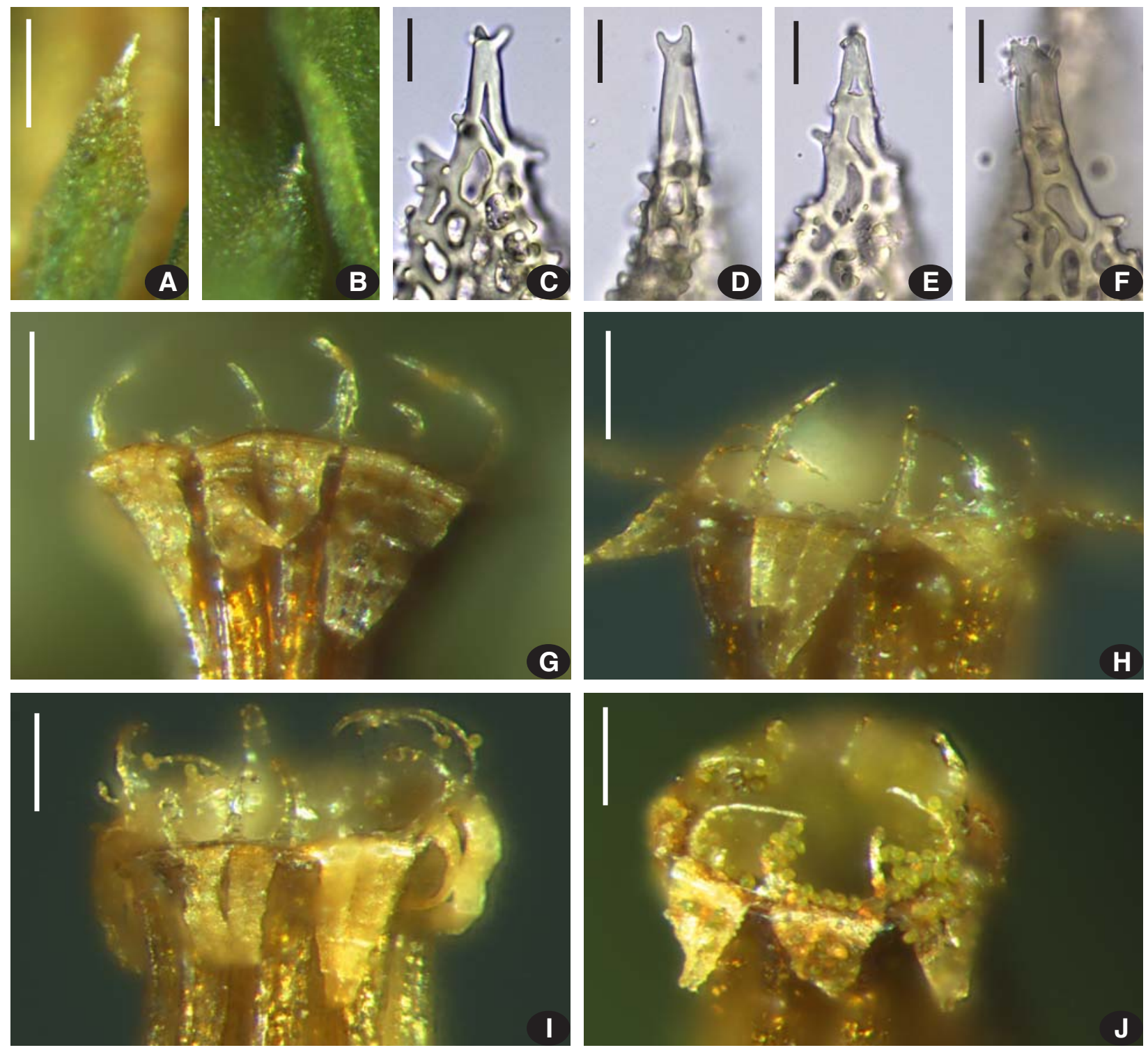

Fig. 2. Orthotrichum hyperboreum. Leaf tips (A-F, all from holotype) and peristomes (G-J, from: G: Taimyr, Khatanga, Fedosov 08-245, MW; H-I: Yakutia, Ust-Maya, Ignatov 00-203, MHA; J: holotype). Scale bars: $100 \mu \mathrm{m}$ for A-B, G-J; $20 \mu \mathrm{m}$ for $\mathrm{C}-\mathrm{F}$.

hyaline dentils composed of irregularly thickened cell walls; upper laminal cells elongate or isodiametric, (9-)1216(-18) 9-12 $\mu \mathrm{m}$, with (1-)2-3 simple or branched papillae per cell, moderately thick-walled, 1(-2) apical cells hyaline, elongate, ca. 20-35 $\mu \mathrm{m}$, few cells below it with thicker walls, often decolorized, with high, spine-like protruding papillae; basal laminal cells rectangular, (14-) 19-34 $(-40) \times 8-14 \mu \mathrm{m}$, with moderately thickened walls, smooth, somewhat narrower and shorter toward margins, short rectangular to subquadrate along margin. Goniautoicous. Perichaetial leaves not differentiated. Vaginula with few (2-3) short hairs. Setae 0.2-0.5 mm, spirally twisted, mostly straight. Capsules immersed to short emergent, oblong-cylindrical, later urceolate, 1.2-1.6 mm long, yellowish, later reddish-brown, deeply 8-furrowed at nearly entire urn length, urns sharply tapering to the seta, without neck, somewhat constricted below mouth.
Stomata in two rows in central and lower part of capsules, immersed, in the middle part of capsules half- or somewhat stronger covered with subsidiary cells, at capsule base almost free; exothecial bands of (3-)4(-6) cells rows. Peristome double, prostome not observed. Exostome teeth in 8 pairs, not split when mature, incurved when wet, reflexed and appressed to capsule wall when dry, fragile, orange-red; outer surface (OPL) transversely striolate in 1-2 proximal cells, in proximal part finely papillose; inner surface (PPL) indistinctly striolate proximally, finely papillose distally. Endostome with low, 23 cells high basal membrane, typically of 16 (8 longer + 8 shorter) brownish segments composed of two cell rows, smooth or indistinctly striolate on outer surface, weakly papillose on inner surface, longer than teeth or nearly of the same length, intermediate segments fragile, occasionally absent; in some specimens capsules with 16 appen- 

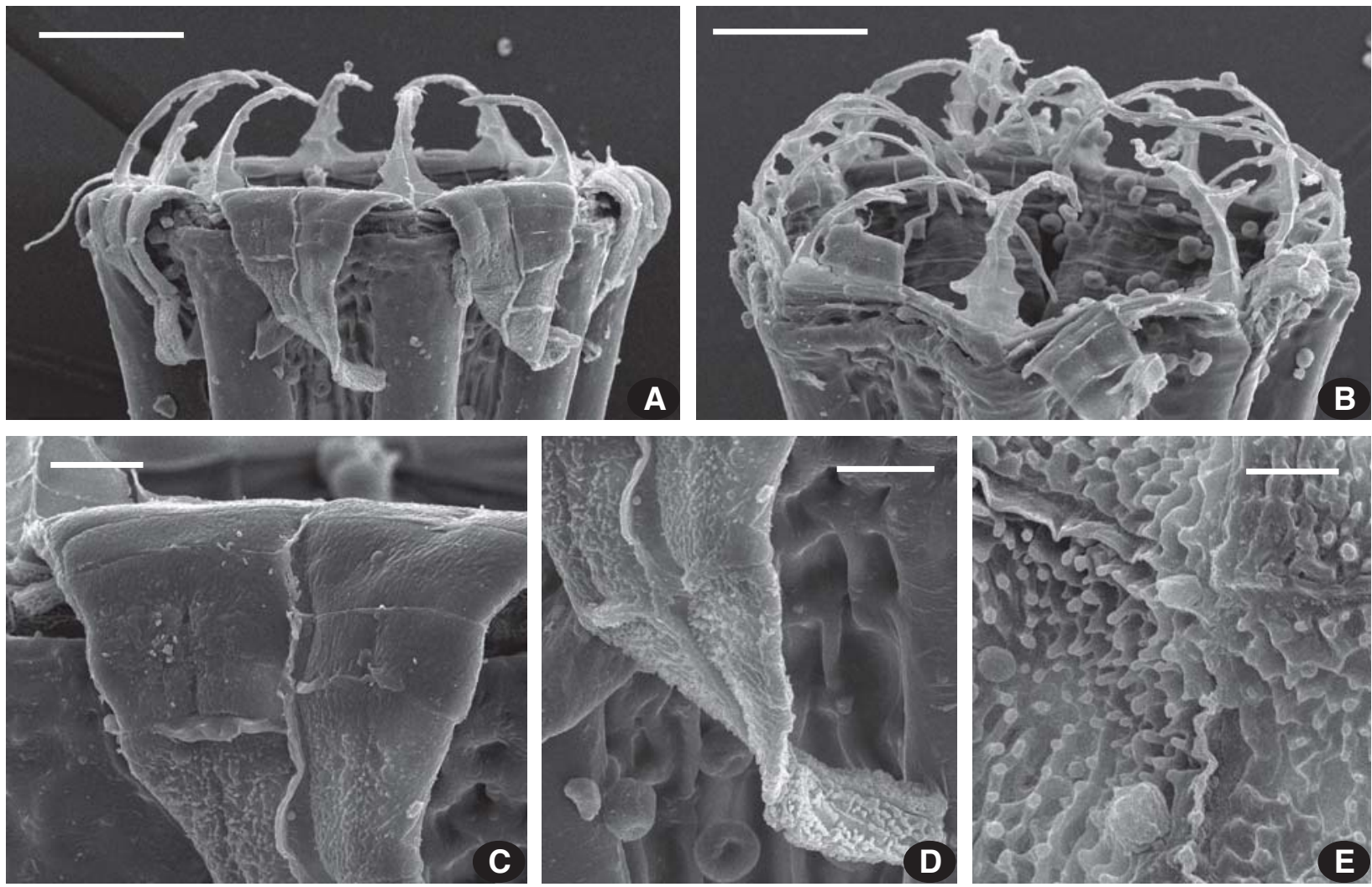

Fig. 3. Peristome of Orthotrichum hyperboreum: A-B - general view; C - vertral surface of proximal to middle part of exostome tooth; D - vertral and partly dorsal (closer to tip) surface of upper part of exostome tooth; E - dorsal surface of proximal part of exostome tooth. Scale bars: $100 \mu \mathrm{m}$ for A-B, $20 \mu \mathrm{m}$ for C-D, $5 \mu \mathrm{m}$ for E.

diculate segments of equal length occasionally occur. Operculum red-rimmed, with rather long beak. Spores papillose, brownish, 13-18 $\mu \mathrm{m}$. Calyptra campanulate, opaque, whitish, with dark brown apices and 8 sharp plicae, naked, smooth.

Distribution and ecology. Orthotrichum hyperboreum seems to be rather widespread in montane hypoarctic areas of Asia (Fig. 5), at least we found it being not rare in some areas of Kotuyskoe Plateau, Khara-Tas Range, Anabar Plateau and Polar Ural, with one locality in Byrranga Range, Arctic Taimyr. Besides this, we revealed two specimens from Yakutia (Orulgan Range and UstMaya Distr.) and one from Chukotka. Typically, this species grows in moist, shaded niches of basaltic, dolerite, andesite, gneiss, gabbro and dunite rocks (once it was collected on bark of spruce) in upper part of forest belt and above/northward of timberline, up to $1500 \mathrm{~m}$ a.s.1. in Yakutia.

Specimens examined: ASIAN RUSSIA: Yamal-Nenets autonomous District: vicinity of Laborovaya settl., Nyarovoyhadata creek upper course, 13.VIII.2017, Fedosov 17-2-136-1 (MW); the same area, 15.VIII.2017, Fedosov 17-2-170-1 (MW); Krasnoyarsk Territory, Taimyr Municipal District: Taimyr Peninsula, Byrranga Mts near northern shore of Ledyanaja Bay of Taimyr Lake, Perevalny Creek middle course, 17.VII.2004, Fedosov (MW 9049167); Kotuyskoe Plateau, Maymecha River valley along Kogotok Creek, 26.VI.2009, Fedosov (MW 9051242); vicinity of Medvezhja River mouth, 13.VII.2005,
Fedosov (MW 9049165); the same area, Ary-Dzhang Plateau, 20.VII.2005, Fedosov (MW 9049166); Kotuy River valley near Potakaj Creek mouth, 18.VIII.2011, Fedosov (MW 9051239); the same place, 16.VIII.2011, Fedosov (MW 9051241); Anabar Plateau, Kotuykan River valley $7 \mathrm{~km}$ upstream Merkyu River mouth, 21.VII.2011, Fedosov (MW 9051240); north periphery of the Anabar Plateau, slope of Fomich River valley 3 km upstream its mouth, 17.VII.2008, Fedosov (MW 9049164); the same area, 11.VII.2008, Fedosov 08-418 \{MHA\}; Rossokha River middle course near Pestrye Skaly area, Sakha-Yuryakh Creek Mouth, 27.VII.2008, Fedosov 08-181 (MHA). Republic Sakha (Yakutia): Eveno-Bytantaysky Distr., Orulgan Range, Tumara Creek valley, 31.VII.2011, Ignatov (MW 9051243); Ust-maya Distr., Tarbagannakh Creek, $61^{\circ} 07^{\prime} \mathrm{N}, 138^{\circ} 16^{\prime} \mathrm{E}$, 1200-1600 m a.s.l., Ignatov 00-203 (MHA). Chukotsky Autonomous Distr.: southern extremity of Pekul'ney Range, middle course of South Pekul'neyveem River, 8.VIII.1979, Afonina s.n. (LE).

Differentiation. Due to the elongate hyaline apical cell or hyaline-dentate leaf apex, which is easy to recognize in the field, specimens of $O$. hyperboreum somewhat resemble Zygodon, but immediately differ in abundant sporophyte production, with immersed to emergent capsules, strongly 8-ribbed, with well-developed double peristome, and naked campanulate calyptrae. Due to continental Subarctic distribution and remarkable habitats, where no one Orthotrichum species excepting O. sibiricum grows, $O$. hyperboreum can be easily recognized. It differs from $O$. sibiricum in obtuse to apiculate leaves 


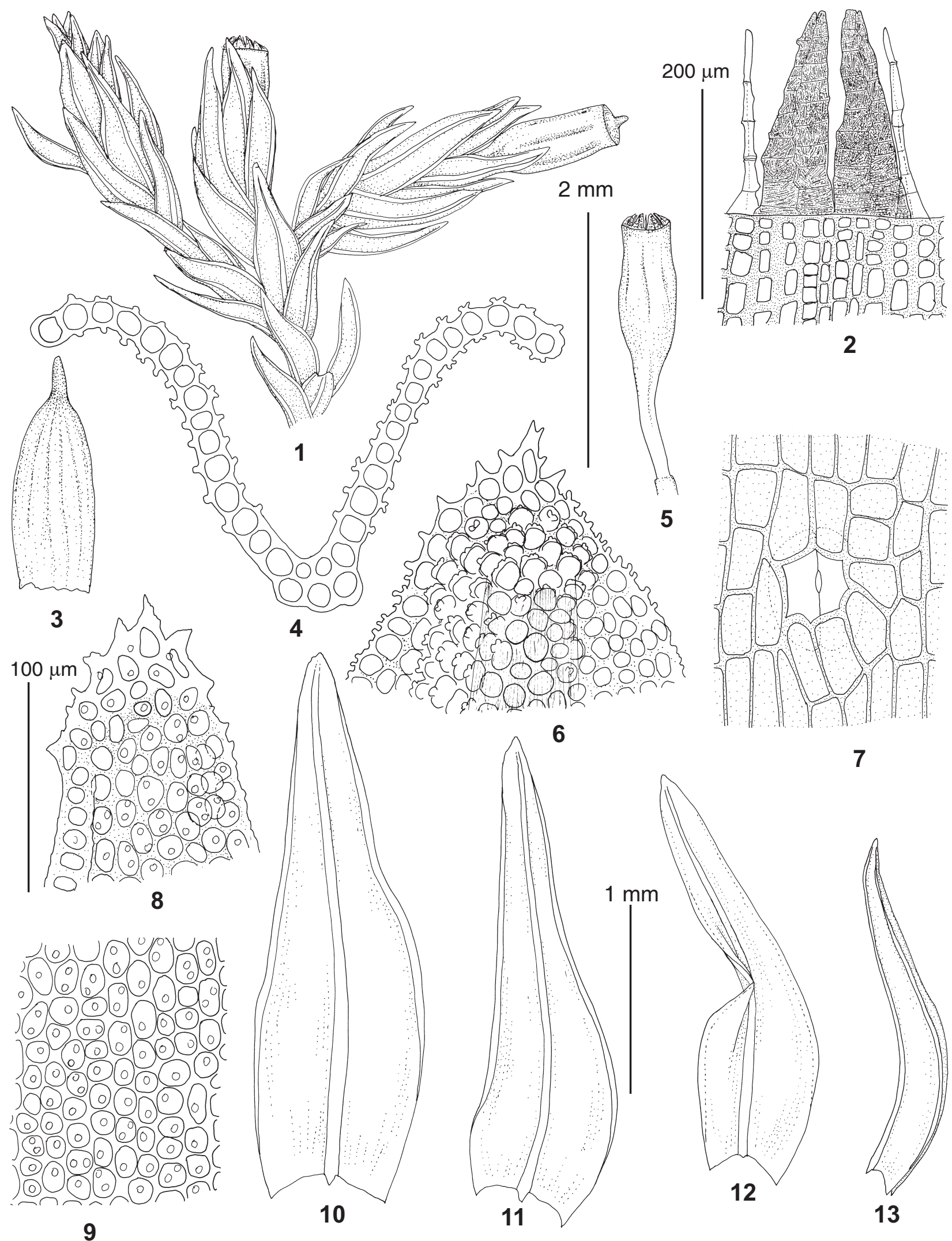

Fig. 4. Orthotrichum hyperboreum (from holotype). 1 - habit, dry; 2 - peristome; 3 - calyptra; 4 - leaf transverse section; 5 capsule; 6, 8 - apical portions of leaf; 7 - exothecial cella and stoma; 9 - median laminal cells; 10-13-leaves. Scale bars: $2 \mathrm{~mm}$ for $1,2,5 ; 1 \mathrm{~mm}$ for $10-13 ; 200 \mu \mathrm{m}$ for $2 ; 100 \mu \mathrm{m}$ for $4,6-9$. 


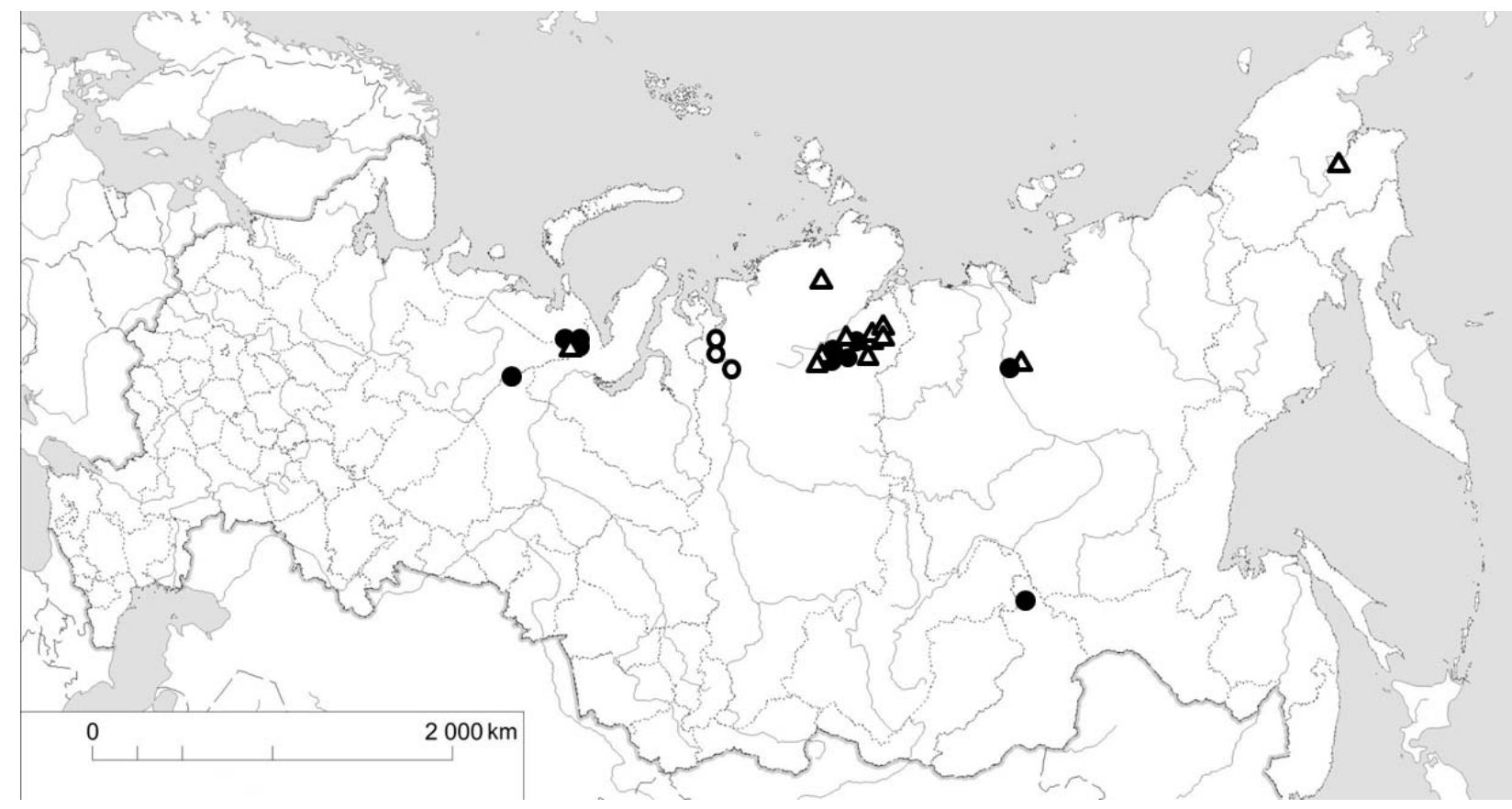

Fig. 5. Distribution of $O$. sibiricum (circles) and O. hyperboreum (triangles). Open circles indicate Arnell's collection in Yenisei River valley made in 1876 , which were mentioned in the protologue.

(vs. acute, not apiculate), peristome constitution, immersed to emergent capsules vs. emergent to exerted ones, and dentate leaf apex. The differences from predominantly saxicolous $O$. alpestre include naked calyptrae and 16 endostome segments. Recently described from the Alps O. dentatum T.Kiebacher \& Lüth has hairy calyptrae, 8 hyaline segments and teeth at upper leaf margins spreading lower (Kiebacher \& Lüth, 2017). Orthotrichum pallens is very diverse in morphology and occasionally occurs on boulders and concrete blocks; it differs from $O$. hyperboreum in having obtuse, never apiculate or distally dentate leaves, mostly simple papillae, temperate/ hemiboreal distribution, and it likely is absent in most part of Asiatic Russia.

\section{ACKNOWLEDGEMENTS}

Authors are greatly indebted to Interregional Expedition Center "Arctic" for arrangement of the field work in Polar Ural, resulted in fresh specimens of both species. The work on SEM was performed partially at User Facilities Center of M.V. Lomonosov Moscow State University under financial support of Ministry of Education and Science of Russian Federation. We are also grateful to curators of S, MHA and LE and to Misha Ignatov for valuable comments and correction of English of the manuscript. The work was partially supported by RFBR ą \#1529-02647 and 15-04-06027.

\section{LITERATURE}

[AFONINA, O.M.] АФОНИНА О.М. 2004а. Конспект флоры мхов Чукотки. - [Moss flora of Chukotka] СПб, БИН РАН [Sankt-Petersburg, Bot. Inst. RAS], $260 \mathrm{pp}$.

[AFONINA, O.M., I.V. CZERNYADJEVA, E.A. IGNATOVA \& YU.S. MAMONTOV]. АФОНИНА О.М., И.В. ЧЕРНЯДЬЕВА, Е.А. ИГНАТОВА, Ю.С. МАМОНТОВ. 2017. Мхи Забайкальского края.
- [Mosses of Zabaikalsky Territory] С-Пб., ЛЭТИ [St. Petersburg, Publishing house of ETU], $301 \mathrm{pp}$.

EDGAR, R.C. 2004. MUSCLE: multiple sequence alignment with high accuracy and high throughput. - Nucleic Acids Research 32: 1792 1797.

FEDOSOV, V.E., E.A. BOROVICHEV, E.A. IGNATOVA \& V.A. BAKALIN. 2015. The bryophyte flora of Eriechka River upper course (SE Taimyr) with comments on the first record of Pseudoditrichum mirabile in Asia. - Arctoa 24 (1): 165-186.

FEDOSOV, V.E. \& E.A. IGNATOVA. 2005. Bryophyte flora of the "Ledyanaya Bay" Key plot (Byrranga Range, Taimyr, Siberian Arctic).Arctoa 14: 71-94.

FEDOSOV, V.E., E.A. IGNATOVA \& O.V. IVANOV. 2009. Orthotrichum holmenii Lewinsky-Haapasaari (Orthotrichaceae, Musci), a new species for Russian moss flora. - Arctoa 18: 195-200.

FEDOSOV, V.E., E.A. IGNATOVA, M.S. IGNATOV \& A.I. MAKSIMOV.2011. Rare species and preliminary list of mosses of Anabar Plateau (Subarctic Siberia). - Arctoa 20: 153-174.

FELSENSTEIN, J. 1985. Confidence limits on phylogenies: an approach using the bootstrap. - Evolution 39: 783-791.

FIEDOROW, P., I. ODRZYKOSKI \& Z. SZWEYKOWSKA-KULINSKA. 1998. Phylogenetic studies of liverworts using molecular biology techniques. - In: J. Maluszynska (ed.). Plant Cytogenetics: Spring Symposium, Cieszyn, 19-22 May 1997. Wydawnictwo Uniwersytetu Slaskiego, Katowice, Poland: 244-249.

GARDINER, A., M. IGNATOV, S. HUTTUNEN \& A. TROITSKY. 2005. On resurrection of the families Pseudoleskeaceae Schimp. and Pylaisiaceae Schimp. (Musci, Hypnales). - Taxon 54: 651-663.

HALL, T.A. 1999. BioEdit: a user-friendly biological sequence alignment editor and analysis program for Windows 95/98/NT. - Nucleic Acids Symposium Series 41: 95-98.

IGNATOV, M.S., O.M. AFONINA, E.A. IGNATOVA et. al. 2006. Checklist of mosses of East Europe and North Asia. - Arctoa 15: 1-130.

IGNATOV, M.S., V.G. ISAKOVA \& E.A. IGNATOVA. 2014. A contribution to the moss flora of Orulgan Range (Yakutia). - Arctoa 23: 194-206.

[IGNATOVA, E.A., M.S. IGNATOV, N.A. KONSTANTINOVA, V.I. ZOLOTOV \& V.G. ONIPCHENKO] ИГНАТОВA E.A., М.С. ИГНА- 
ТОВ, Н.А. КОНСТАНТИНОВА, В.И. ЗОЛОТОВ, В.Г. ОНИПЧЕНКО. 2008. Флора мохообразных Тебердинского заповедника. [Bryophytes of Teberdinskiy State Nature Reserve] Флора и фауна заповедников [Flora i fauna zapovednikov] 112: 1-86.

IGNATOVA, E.A., O.I. KUZNETSOVA, V.E. FEDOSOV \& M.S. IGNATOV. 2016. On the genus Hedwigia (Hedwigiaceae, Bryophyta) in Russia. - Arctoa 25 (2): 241-277.

[KAZANOVSKY, S.G.] КАЗАНОВСКИЙ С.Г. 1991. К бриофлоре Байкальского заповедника. - [On the bryoflora of Baikal Reserve]. Бриология в СССР, ее достижения и перспективы (Мат. конф., Львов, 10-12 сент. 1991) (ред. Демкив, О. Т.), Львов, АН СССР, AH YCCP [In: Demkiv, O. T. (ed.), Briologia v SSSR, ee dostizheniya i perspektivy (Proc. Conf., Lvov, 10-12 Sept. 1991). Lvov, Akad. Nauk SSSR \& Akad. Nauk Ukr. SSR]: 94-98.

KIEBACHER, T. \& M. LÜTH. 2017. Orthotrichum dentatum T. Kiebacher \& Lüth sp. nov. (Orthotrichaceae). - Journal of Bryology 39(1): $46-56$.

LEWINSKY, J. 1977. The family Orthotrichaceae in Greenland. A taxonomic revision. - Lindbergia 4: 57-103.

LEWINSKY, J. 1993a. A synopsis of the genus Orthotrichum Hedw. (Musci, Orthotrichaceae). - Bryobrothera 2: 1-59.

LEWINSKY, J. 1993b. Notes on some species of Orthotrichum Hedw. (Musci) from Europe, the Caucasus and North Africa. - Bryobrothera 2: 71-76.

LEWINSKY-HAAPASAARI, J. 1995. Illustrierter Bestimmungsschlüssel zu den europäischen Arten der Gattung Orthotrichum. - Meylania 9: 3-57.

LEWINSKY-HAAPASAARI, J. 1996. Orthotrichum holmenii, a new corticolous species from Kazakhstan with comments on Orthotrichum hallii in Asia. - Bryologist 99(1): 1-5.
LINDBERG, S.O. \& H.W.ARNELL 1890. Musci Asiae Borealis. - Kongl. Svenska Vetensk.-Akad. Handl. 23(10): 1-163.

LÖNNELL, N. 2008. Orthotrichaceae. - In: Nationalnykeln till Sveriges flora och fauna. Bladmossor: Sköldmossor-bllmossor. Bryophyta: Buxbaumia-Leucobryum. Uppsala, 220-275.

MEDINA, R., R. GARILLETI, V. MAZIMPAKA \& F. LARA. 2009. A new look at Orthotrichum scanicum Gronvall (Orthotrichaceae, Bryophyta). - Journal of Bryology 31: 86-92.

RAMBAUT, A. \& A.J. DRUMMOND. 2007. Computer program and documentation distributed by the author, website http://beast. bio.ed.ac.uk/Tracer.

RONQUIST, F., M. TESLENKO, P. VAN DER MARK, D.L. AYRES, A. DARLING, S. HÖHNA, B. LARGET, L. LIU, M.A. SUCHARD \& J.P. HUELSENBECK. 2012. MrBayes 3.2: Efficient Bayesian phylogenetic inference and model choice across a large model space. - Systematic Biology 61: 539-542.

SAWICKI, J., V. PLÁŠEK \& M. SZCZECIŃSKA. 2012. Molecular data do not support the current division of Orthotrichum (Bryophyta) species with immersed stomata. - Journal of Systematics and Evolution 50(1): $12-24$

STAMATAKIS, A. 2006. RAxML-VI-HPC: maximum likelihood-based phylogenetic analyses with thousands of taxa and mixed models. - Bioinformatics 22: 2688-2690.

WARNSTORF, C. 1913. Zur Bryogeographie des Russischen Reiches.Hedwigia 53: 184-320.

WIJK, R. VAN DER, W. D. MARGADANT \& P. A. FLORSCHUTZ. 1964. Index Muscorum. 3 (Hypnum-O). - Regnum Vegetabile 33. $529 \mathrm{pp}$.
Appendix 1

species

Lewinskya speciosa

Lewinskya speciosa

Lewinskya speciosa

Orthotrichum anomalum

Orthotrichum anomalum

Orthotrichum anomalum

Orthotrichum hyperboreum

Orthotrichum hyperboreum

Orthotrichum hyperboreum

Orthotrichum hyperboreum

Orthotrichum hyperboreum

Orthotrichum pallens

Orthotrichum pallens

Orthotrichum pallens

Orthotrichum pallens

Orthotrichum pallens

Orthotrichum pumilum

Orthotrichum scanicum

Orthotrichum sibiricum

Orthotrichum sibiricum

Orthotrichum sibiricum

Orthotrichum sibiricum

Orthotrichum stramineum

Orthotrichum tenellum code Locality

OF31

OF55

OF70

OF4

OF5

OF25

OF20

OF22

OF51

OF59

OF60

OF19

OF39

OF63

OF52

OF53

OF26

OF79

OF11

OF12

OF58

OF61

OF33

OF40
Vladimir Province

Moscow Province

Kursk Province

Anabar Plateau 1

Anabar Plateau 2

Anabar Plateau 3

Anabar Plateau 1

Yakutia, Orulgan Range

Anabar Plateau 2

Polar Ural 1

Polar Ural 2

Lipetsk Province 1

Bashkortostan Republiń

Ryazan' Province

Lipetsk Province 2

Karachaevo-Circassian

Belgorod Province

Karachaevo-Circassian

Anabar Plateau 1

Anabar Plateau 2

Polar Ural

Subpolar Ural

Karachaevo-Circassian

Krasnodar Territory
Herbarium \& specimen ID

MW 9051449

MW 9051488

MW 9051539

MW 9050960

MW 9050972

MW 9051249

MW 9051240

MW 9051243

MW 11-1365

MW 17-2-170-2

MW 17-2-136-1

MW 9051214

MW 9051238

MW 9051206

MW 9051217

MW 9051232

MW 9051271

MW 9051368

MW 9051023

MW 9049168

MW 17-2-115-1

MW 9051021

MW 9051587

MHA M-221
GB accession number

MG697238

MG697239

MG697240

MG697242

MG697241

MG697243

MG697248

MG697249

MG697250

MG697251

MG697252

MG697258

MG697257

MG697261

MG697260

MG697259

MG697254

MG697256

MG697244

MG697245

MG697246

MG697247

MG697255

MG697253 